\title{
THE ROLE OF THE SCHOOL LIBRARY IN CHANGE AND PEDAGOGICAL INNOVATION
}

\author{
G. Bastos ${ }^{1}$, I. Matias ${ }^{2}$ \\ ${ }^{1}$ Universidade Aberta (PORTUGAL) \\ ${ }^{2}$ Agrupamento de Escolas Manuel Teixeira Gomes, Universidade Aberta (PORTUGAL)
}

\begin{abstract}
In this paper we present the results of a research study, specifically focused on the way school leaders (principals), primary classroom teachers and teacher librarians from two grouping of schools in the south region of Portugal look at the School Library (SL). We have analysed the integration of the school library in teaching and learning activities and the role of the school library in processes of change and pedagogical innovation, namely based on the use of technologies. A survey was applied to 40 primary school teachers. Two principals, two assistant professors of principals, and four teacher librarians from the two grouping of schools were submitted to interviews. The quantitative and qualitative data were analysed and results show some differences between the two primary schools.

In general, the participants in the study agreed that there is a positive effect of the SL on the teaching practices of the teachers. The SL is felt as an alternative learning space to the classroom, in the development of different methodologies and practices. The proposals and changes recommended by the teacher librarian were incorporated into the teaching strategies of teachers in a gradual way, as they realized the added value. The idea of the school library functioning as a nucleus for implementing innovations did not raise doubts. However, in practice, this situation is not always easy to achieve, with several factors influencing this dimension, namely the profile of teachers in each school and teacher librarians' time availability to work with classroom teachers.
\end{abstract}

Keywords: School Library, Learning environment, Pedagogical innovation.

\section{INTRODUCTION}

The School Library Network (SLN; in Portuguese language, RBE) was created in 1996 by the Ministry of Education in partnership with the Ministry of Culture. This Program had as main objective the installation of school libraries in public schools, whatever the level of education. These libraries would function as centres of multimedia resources and would serve the entire educational community where the school was located. They would be freely accessible, in adequate physical space and with quality material resources and in quantity depending on the number of students. For many schools, this scenario was completely new and would cause major changes in the school organization as a whole, both for students, in terms of their greater autonomy and accountability, and for teachers, as they felt the need to communicate and collaborate more, within and outside schools.

More than 20 years after the beginning of this Network, School Libraries (SL) have now a dedicated Teacher Librarian, and are important means for the development of skills in the various literacies, reading, information and media literacy, providing users with the necessary resources for reading, accessing, using and producing of information in different supports. And several guidelines that are produced by the SLN give important orientations to the work that SL have to do (see, for example, [1] [2]).

In 2010 it was conceived and implemented a self-evaluation model for the SL [3]. Key concepts such as value, impact and evidence-based practice have supported the way the model was conceived [4] [5]. Resources and processes are important only in the measure of their added value and contribution to develop teaching and learning. At the same time, multiple institutional initiatives emerged to promote the modernization of primary schools and the change and innovation in teachers' pedagogical practices. In the last twenty years, there have been several initiatives aimed at changing primary schools in Portugal (1st cycle of basic education) and, which are more or less directly related to the SL's field of action. These measures were considered, as ambitious in international reports [6], bringing to Portugal some good practices implemented in other countries, although "they have been carefully adapted to the Portuguese context, to respond to the country's priorities and challenges" ( $p$. 7). For example, programmes like the National Reading Plan (since 2006), the National Portuguese 
Teaching Plan (2006-2010), or the Technological Education Plan (2007-2011, with different designations since then) had and still have the SL as an important partner.

In this context of change, technology has become an essential element of the school library learning environment, and integrating technology into activities that have the SL as a learning centre is an important way to extend the reach of school libraries in the digital arena. Recent times have shown how important it is to incorporate technologies into teaching and learning processes, and the school library must also play an important role in this context. So, it is fundamental to understand how the SL is facing these issues and how the TL is collaborating with other teachers to improve pedagogical innovations.

In this paper we present a set of results obtained in the context of a broader research study on the role of school libraries in pedagogical innovations. Here we will focus our attention on data related to the way the school leaders (principals), primary classroom teachers and teacher librarians from two grouping of schools in the south of Portugal (Algarve region) face the role of the SL in change and pedagogical innovation.

\section{METHODOLOGY}

Currently, the classic paradigm dichotomy between quantitative and qualitative approaches is outdated. For some authors it is not in a logic of antinomy of paradigms that the processes of educational and social science research should be based [7, 8]. Both approaches are no longer seen as alternative methodological options, but as a continuum, as complementary approaches in scientific research. The collection of data, combining qualitative and quantitative elements, provides an apprehension of the phenomenon under study in all its dimensions, as well as of the dynamic processes that are triggered, that the use of a single approach would not provide.

In the present investigation, qualitative and quantitative procedures were used, in a perspective of mutual enrichment, and as an attempt to understand more fully the phenomena that are the object of study. We chose the case study (multiple cases) that allows the analysis of the particularity and complexity of singular cases, to come to understand a broader set of circumstances that determine certain outcomes [9].

So, a survey was applied to all primary school teachers of two different grouping of schools in the region of Algarve (south of Portugal) with 33 answers (82,5\% of total). The two principals, two assistant teachers of principals, and two teacher librarians from the schools were also submitted to interviews. In the construction of the interviews and questionnaire guidelines, we followed, globally, the same criteria. We intended to capture and analyse the ways the SL and the TL actions are seen by classroom teachers and elements with responsibility in the direction of schools, so we fundamentally favour the perspectives of the research subjects [10].

\section{RESULTS}

In next sections we present and examine the results of the surveys and the interviews. It is important to mention that in Portugal the schools are organized in groups, composed by different levels (sometimes from kinder-garden to $12^{\text {th }}$ grade) with a principal that can have assistant teachers. Some counties decide to concentrate students in big schools and others prefer smaller schools scattered throughout the region.

The two grouping of schools analysed are representative of these two situations: Grouping of Schools A (SA) - with 3 small primary schools located in different parts of the county; and Grouping of Schools $B(S B)$ - with 1 big primary school located in a town. The schools follow the national regulations, with a TL dedicated to the school libraries located in the primary schools, so in SA the TL is responsible for 3 (smaller) school libraries, and in SB the TL is responsible for one school library.

\subsection{The survey}

In SA, in 20 teachers, 18 (16 women; 2 men) responded to the questionnaire ( $90 \%$ return rate); in SB, also with 20 teachers, 15 (all women) answered the questionnaire ( $75 \%$ return rate), values that we consider quite reasonable given the various requests that teachers are usually subject to. The age characterization of those teachers is presented in table 1. 
Table 1. Age characterization of the respondents.

\begin{tabular}{c|c|c|c|c|c|c}
\hline \hline \multirow{2}{*}{ Age } & \multicolumn{2}{|c|}{ SA } & \multicolumn{2}{c|}{ SB } & \multicolumn{2}{c}{ Total } \\
\cline { 2 - 7 } & Freq. & $(\%)$ & Freq. & $\%$ & Freq. & $\%$ \\
\hline$<31$ & 0 & 0 & 0 & 0 & 0 & 0 \\
\hline $31-35$ & 2 & 11 & 4 & 26 & 6 & 18 \\
\hline $36-40$ & 6 & 33 & 3 & 20 & 9 & 28 \\
\hline $41-45$ & 5 & 28 & 1 & 7 & 6 & 18 \\
\hline $46-50$ & 4 & 22 & 1 & 7 & 5 & 15 \\
\hline $51-55$ & 0 & 0 & 2 & 13 & 2 & 6 \\
\hline $56-60$ & 1 & 6 & 2 & 13 & 3 & 9 \\
\hline$>60$ & 0 & 0 & 1 & 7 & 1 & 3 \\
\hline No answer & 0 & 0 & 1 & 7 & 1 & 3 \\
\hline Total & 18 & 100 & 15 & 100 & 33 & 100 \\
\hline \hline
\end{tabular}

These data confirm the situation in Portuguese primary schools: the feminization of the teaching profession [11], [12], and also an aging situation, without young people entering the profession. However, there are some differences in the two contexts, as the SA has most of its teaching staff between 31 and 45 years old, while in the SB there is a greater age dispersion.

The survey applied in the research has several parts, based on a Likert scale: 1 - Totally disagree; 2 Disagree; 3 - Agree; 4 - Totally agree. The results concerning the specific topic analysed in this paper, the role of the SL in change and pedagogical innovation are shown in tables 2 and 3.

Table 2. Results of School A (SA).

\begin{tabular}{|c|c|c|c|c|}
\hline \multirow{2}{*}{ Questions } & \multicolumn{4}{|c|}{$(\%)$} \\
\hline & 1 & 2 & 3 & 4 \\
\hline $\begin{array}{l}\text { 1. SL's practices are linked to the goals and curricular objectives of the school and to the } \\
\text { students' learning. }\end{array}$ & - & - & 93,75 & 6,25 \\
\hline 2. My SL provides resources capable of supporting students' training and curricular path. & - & 12,50 & 87,50 & - \\
\hline 3. I value the SL's role and integrate it into my teaching and learning practices. & - & - & 64,71 & 35,29 \\
\hline 4. The SL has an important role in improving educational practices at my school. & - & - & 80,00 & 20,00 \\
\hline $\begin{array}{l}\text { 5. The work I do with the SL has a positive impact on my students' learning and } \\
\text { educational success. }\end{array}$ & - & - & 76,47 & 23,53 \\
\hline $\begin{array}{l}\text { 6. The SL promotes environments favourable to technological changes and the needs of } \\
\text { users. }\end{array}$ & - & 25,00 & 62,50 & 12,50 \\
\hline $\begin{array}{l}\text { 7. The SL provides information services with content and technological resources } \\
\text { capable of responding to change. }\end{array}$ & - & 33,33 & 60,00 & 6,67 \\
\hline $\begin{array}{l}\text { 8. I have difficulties in linking my work with the SL, because the SL is unable to respond } \\
\text { to my needs. }\end{array}$ & 5,88 & 41,18 & 47,06 & 5,88 \\
\hline 9. The SL develops students' skills in the use of technologies in an educational context. & - & 43,75 & 56,25 & - \\
\hline 10. My SL is a place of learning and training for teachers and students. & - & 25,00 & 68,75 & 6,25 \\
\hline 11. The SL's work improves classroom work in reading projects and activities. & - & 12,50 & 87,50 & - \\
\hline 12. The SL plays a very important pedagogical role at school. & - & 5,88 & 82,35 & 11,76 \\
\hline $\begin{array}{l}\text { 13. The SL has a good capacity to respond to the challenges of the school, supporting } \\
\text { teachers in the development of innovative pedagogical practices. }\end{array}$ & - & 37,50 & 56,25 & 6,25 \\
\hline
\end{tabular}

Analysing the responses referring to the opinion of the teachers of the SA about the pedagogical role of their SL, and looking at the items that were most valued, we can conclude that most of the teachers considered that the SL took a part of some relevance in processes of change and pedagogical innovation. This set of questions, overall, obtained an average of 2.94 (between 2 and 3), with a median of 3 (positive trend) and standard deviation of 0.12 . 
Five items have an average higher than 3 . They stand out as more positive aspects, according to the intensity of the agreeing opinions. These are the elements that best illustrate the role of the SL in the teaching and learning processes:

- Valorisation of the role of the SL and integration in teaching and learning practices (item 3): all responses are in the positive quadrant: $64.71 \%$ of teachers agree and $35.29 \%$ fully agree with this item.

- The work that the teacher develops with the SL has a positive impact on students' learning and educational success (item 5): all the answers are in the positive quadrant: $76.47 \%$ of the teachers agree and $23.53 \%$ fully agree with this statement.

- The SL has an important role in improving the school's educational practices (item 4): all responses are in the positive quadrant: $80 \%$ of respondents agree and $20 \%$ fully agree with this statement.

- The SL plays a very important educational role at school (item 12): with $82.35 \%$ of respondents agreeing and $11.76 \%$ fully agreeing.

- The SL's practices are linked to the goals and curricular objectives of the schools, and to the students' learning (item 1): all answers are in the positive quadrant: $93.75 \%$ of the participants agree and $6.25 \%$ agree totally with this statement.

Nevertheless, other five aspects obtained an average of less than 3 (between 2.53 and 2.88). Therefore, the least valued elements, with regard to the pedagogical role of the SL, were:

- Difficulties in articulating teaching work with the SL (item 8): this question had a negative formulation, to control the involvement and attention of respondents to the questionnaire. We note that there is consistency in the responses. In this case, $52.94 \%$ of the answers are in the positive quadrant - negative assessment - with 47.06 of the respondents agreeing that the SL is unable to respond to the needs of the teachers. Perhaps due to the difficulty in combining the classroom work with the presence of the TL in each SL (we remember that in SA the TL is responsible for $3 \mathrm{SL}$ located in 3 different primary schools and has to circulate among them during the week).

- Development of students' skills in the use of technologies in an educational context (item 9): this item has an average of 2.56, and median 3 (positive trend). The frequency scales with the highest incidence were $56.25 \%$ agree and $43.75 \%$ disagree. This result shows a clear division between teachers' opinions on this aspect. Other issues related to the SL offer in the field of technologies also had less positive appraisals, which means that this is one of the most fragile aspects.

- Ability to respond to the challenges of the school, supporting teachers in the development of innovative teaching practices (item 13): this item has an average of 2.69, median 3 (positive trend). The frequency scales with the highest incidence were $56.25 \%$ agree and $37.50 \%$ disagree. Only $6.25 \%$ of the teachers fully agreed with this statement. These results show that the $\mathrm{SL}$ is somehow failing in its mission to support pedagogical innovation.

Table 3. Results of School B (SB).

\begin{tabular}{|c|c|c|c|c|}
\hline \multirow[t]{2}{*}{ Questions } & \multicolumn{4}{|c|}{ (\%) } \\
\hline & 1 & 2 & 3 & 4 \\
\hline $\begin{array}{l}\text { 1. SL's practices are linked to the goals and curricular objectives of the school and to } \\
\text { the students' learning. }\end{array}$ & - & - & 93,33 & 6,67 \\
\hline 2. My SL provides resources capable of supporting students' training and curricular path. & - & - & 86,67 & 13,33 \\
\hline 3. I value the SL's role and integrate it into my teaching and learning practices. & - & - & 66,67 & 33,33 \\
\hline 4. The SL has an important role in improving educational practices at my school. & - & - & 80,00 & 20,00 \\
\hline $\begin{array}{l}\text { 5. The work I do with the SL has a positive impact on my students' learning and } \\
\text { educational success. }\end{array}$ & - & - & 73,33 & 26,67 \\
\hline $\begin{array}{l}\text { 6. The SL promotes environments favourable to technological changes and the needs } \\
\text { of users. }\end{array}$ & - & 6,67 & 80,00 & 13,33 \\
\hline $\begin{array}{l}\text { 7. The SL provides information services with content and technological resources } \\
\text { capable of responding to change. }\end{array}$ & - & 30,77 & 61,54 & \begin{tabular}{|l}
7,69 \\
\end{tabular} \\
\hline
\end{tabular}




\begin{tabular}{|c|c|c|c|c|}
\hline $\begin{array}{l}\text { 8. I have difficulties in linking my work with the SL, because the SL is unable to respond } \\
\text { to my needs. }\end{array}$ & 26,67 & 6,67 & 66,67 & - \\
\hline 9. The SL develops students' skills in the use of technologies in an educational context. & - & 13,33 & 80,00 & 6,67 \\
\hline 10. My SL is a place of learning and training for teachers and students. & - & - & 86,67 & 13,33 \\
\hline 11. The SL's work improves classroom work in reading projects and activities. & - & - & 73,33 & 26,67 \\
\hline 12. The SL plays a very important pedagogical role at school. & - & - & 73,33 & 26,67 \\
\hline $\begin{array}{l}\text { 13. The SL has a good capacity to respond to the challenges of the school, supporting } \\
\text { teachers in the development of innovative pedagogical practices. }\end{array}$ & - & 13,33 & 73,33 & 13,33 \\
\hline
\end{tabular}

It appears that the opinions of teachers working in SB are more positive comparing with the results of SA. The majority of the teachers of the SB considered that the SL has played a positive role in supporting pedagogical innovation. Overall, this set of questions, and excluding the control item, has obtained an average of 3.12 (between 3 and 4), with a median of 3 (positive position) and standard deviation 0.09 .

Effectively, ten items in thirteen have an average equal to or greater than 3 . The highest levels of agreement cover the following aspects:

- Valorisation of the role of the SL and integration in teaching and learning practices (item 3): all responses are in the positive quadrant, that is, $66.67 \%$ of teachers agree and $33.33 \%$ fully agree.

- Simultaneously, three items "The work that the teacher develops with the SL has a positive impact on students' learning and educational success" (item 5), "There is an improvement in the SL's work with classes in reading projects and activities" (item 11), and "The SL plays a very important pedagogical role in the school" (item 12) obtained equal results: all the answers are in the positive quadrant, that is, $73.33 \%$ of the teachers agree and $26.67 \%$ fully agree with this statement.

- The SL has an important role in improving the school's educational practices (item 4): all responses are in the positive quadrant: $80 \%$ of respondents agree and $20 \%$ fully agree with this statement.

- Together, the items "The SL of my school provides resources capable of supporting the students' training and curricular path" (item 2) and "The SL of my school is a place of learning and training for teachers and students" (item 10) achieved the same result: the totality of the responses are grouped in the positive quadrant in which $86.67 \%$ of the respondents agree and $13.33 \%$ fully agree with both statements.

- SL's practices are linked to the goals and curricular objectives of the school and to the students' learning (item 1): all the answers are still in the positive quadrant: $93.33 \%$ of the participants agree and $6.67 \%$ totally agree with this statement.

With some dispersion in the judgment made, we find two situations:

- Promotion of environments favourable to technological changes and user needs (item 6): $80 \%$ of respondents agree; $13.33 \%$ totally agree and only $6.67 \%$ disagree.

- The SL has a good response capacity to the challenges of the school, supporting teachers in the development of innovative pedagogical practices (item 13): $73.33 \%$ of the respondents agree and $13.33 \%$ fully agree and disagree, simultaneously.

All statements in the questionnaire had a median of 3 , which indicates a tendency to agree. However, three elements are viewed in a less positive way, that is, with an average of less than 3 , which we present below:

- Difficulties in combining teaching work with the SL: this question had a negative formulation, to control the involvement and attention of respondents to the questionnaire, verifying consistency in the responses. This fact may be due to the issue of a single teacher (the onçy teacher for all subjects) or, on the other hand, to a real disarticulation with the current TL, which he recognized in the interview given (see below). In this case, $66.67 \%$ of the respondents agreed; $26.67 \%$ totally disagreed and $6.67 \%$ disagreed. 
- Provision of information services with content and technological resources capable of responding to change (item 7): average of 2.77 , median 3 (positive trend). Only $7.69 \%$ of teachers fully agree with this statement. The frequency scales with the highest incidence are I agree with $61.54 \%$; disagree with $30.77 \%$.

- Development of students' skills in the use of technologies in an educational context (item 9): this item has an average of 2.93, median 3 (positive trend). The frequency scales with more incidences are $80 \%$ agree and disagree with $13.33 \%$.

\subsection{The interviews}

As mentioned before, the study includes interviews to 6 persons. Their characterization is presented in table 4.

Table 4. Participants in the interviews.

\begin{tabular}{l|c|c}
\hline \hline & $\begin{array}{c}\text { School A } \\
\text { (age/genre) }\end{array}$ & $\begin{array}{c}\text { School B } \\
\text { (age/genre) }\end{array}$ \\
\hline Principal (P) & $41 / \mathrm{F}$ & $57 / \mathrm{M}$ \\
\hline Assistant teacher of principal (AP) & $48 / \mathrm{F}$ & $51 / \mathrm{F}$ \\
\hline Teacher Librarian (TL) & $51 / \mathrm{F}$ & $45 / \mathrm{M}$ \\
\hline \hline
\end{tabular}

The interviews followed the same topics covered in the survey, and concerning the topic we examine in this paper, the 6 participants discussed the educational role of the school library, analysing the specific situation of each school. As for the survey, we first present the overall results of SA and after SB.

Regarding a positive change in the pedagogical practices of the teachers of SA due to the contribution of the SL, all the interviewees agreed with this aspect. One of them said that "the question of reading and encouraging reading [...] was a pedagogical practice of teachers that has changed thanks to the existence of the SL" (P). The advantages listed by the interviewees are still related to the domain of reading, "requisition of the book, reading" $(P)$, and "reading in the classroom in view of the offer that the library makes to classes [...] reading in pairs [...] silent reading" (AP). The proactive position of the teacher librarian is evidenced mainly in reading activities done in the library or in the classroom with the guidance of the TL and that this practice "is passed on to the classroom teachers and enriches their pedagogical work with pupils" (AP). The TL describes the work with the classroom teachers in the following way: "when I started there was a certain reluctance to go to the library because they thought it was a waste of time. Currently, I think not, the SL has been an asset. The SL is very much used, by all teachers but, mainly, for reading activities. Many reading activities. Sometimes, children go there just to be reading".

We verified that the SL of SA is considered as a nucleus for implementing innovations by only two of the interviewees. The other interviewee had a more reticent position: "that it can be a nucleus for implementing innovations, I have no doubt [...]. In practice, it is not that is easy to do it" (P). As one interviewee confidently stated, "everything depends a lot on the creativity of the team, the teachers, on new ways of presenting the material and all the resources that are in the SL [...] to present it in a more motivating way for the students" (AP).

The measures recommended by the interviewees to improve the quality of the pedagogical work of the SL point out, in the first place, the need for technological devices - computers and other tools (P; TL). In this context, it was not surprising that the TL referred the urgency of "computers because at the moment they are super outdated [...]. They have better devices at home than what is there". This answer deserves our attention, we remember that the current IFLA Guidelines for the school library [13] point to the existence of computers with an Internet connection, and other production equipment necessary for practical learning activities, to support students in the research, analysis, synthesis and communication of information in a meaningful way. In other words, an orientation that was not verified in the reality of the SL of SA. The interviewees also indicated the following conditions for the improvement of the SL: more joint planning work between the TL and classroom teachers; update SL resources; extend the opening hours of the library.

Concerning SB, the participants in the interview confirmed that the SL has an important pedagogical role, stating that there is "greater opening of the classroom space to other educational contexts, where 
the SL functions as an alternative learning space, with different educational contexts and with different methodologies and with different practices" $(P)$, and also "A motivation; an incentive; a commitment, often from the teacher to the library that leads teachers to do activities that they would not do if they did not have that commitment" (AP). One the other hand, the TL says that "some teachers are receptive to the proposals we bring. It is noted that some of them had never been thought or thought along those lines and once they are adopted and put into practice, I think there is really a pedagogical improvement".

The functioning of the SL as a nucleus for implementing innovations was ensured by the interviewees, having hesitated when stating "theoretically yes, as long as there is the possibility to prepare the activities and implement them, which in this moment is being very difficult" (TL). The ICT area was the most mentioned topic as an element that can introduce innovations. It was also mentioned "the training that TL also had on ICT and on the Technological Plan, which was later reflected in the practice of teachers in their day-to-day activities" (TL). Besides, according to this interviewee, the SL is in charge of developing the goals of the National Reading Plan and has to connect with other national programmes, and this is a benefit for all, teachers and pupils.

In relation to the measures recommended to improve the quality of the pedagogical work of the SL in $\mathrm{SA}$, the interviewees expressed, in the first place and explicitly, the need for more human resources $(P, T L)$. They also mention some lack of resources: the school can build new projects but they need more resources.

\section{CONCLUSIONS}

In general, teachers from the two school groups analysed perceive the school library as a structure that supports and encourages pedagogical change and innovation, which clearly shows the tendency to comply with the standards set out by the SLN Programme. This appraisal is in line with the results of other studies carried out on school libraries in Portugal, which consider that the library is present in the schools' "change and innovation projects", but above all in terms of promoting reading [14] [15]. This perspective is also found in international studies that identify the school library as a nucleus of innovation within schools [16].

We have also confirmed that there are some differences in the way teachers in both schools assess the educational role of the library. We recall that at School A the global average was below 3 , although slightly (2.94) and at school B above 3 (3.12), denoting a more positive evaluation of the library's action and, of course, also of its responsible, the librarian teacher, as contemplated in Portuguese legislation.

These differences are justified by several factors. In terms of teaching staff, through the characterization that was made, it was found that at School A the teaching staff is less stable and have less service time, which may indicate a weaker connection to the school and its library and also less possibilities of continuing some projects. However, we consider that the main reason for the differences noted in the opinion issued on some dimensions of the educational role of the school library will be related to organizational issues, namely the functioning of schools in groups.

In fact, and as we noted in the characterization of the context of schools analysed, in grouping of schools A (SA) there are three libraries in three smaller schools that are distant from each other. It seems to us, and our professional experience demonstrates this fact, that on days when the teacher librarian is not present at school, the SL is understood as closed. And the lack of this presence is reflected in the (dis) satisfaction of the needs of teachers. We believe that this issue could have been further explored during the interview with the TL of this group of schools. Teachers' dissatisfaction with the SL's opening hours was only recorded at this school, which seems to be related to the situation described. In grouping of schools B (SB) the reality is different, there is only one large school with a library. In this school, organizational aspects are less focused.

All respondents also agreed to changes for the better in the pedagogical practices of teachers in the 1 st cycle of basic education due to the contribution of the SL. Once again the main value of the library fell predominantly in the domain of reading, in both groups, also focusing on writing, vocabulary, orality and Curricular Goals of Portuguese Language. The school library is seen as an alternative learning space to the classroom, in the development of different methodologies and practices (especially in $\mathrm{SB})$. Some new pedagogical strategies proposed by the teacher librarian were incorporated into the teaching practices in a gradual way, as teachers realized the added value. 
The idea of the School Library to function as a nucleus for implementing innovations did not raise doubts for the interviewees. However, in practice, this situation is not always easy to achieve, with several factors influencing this dimension. Respondents recommended several measures to improve the quality of the SL's pedagogical work, with great harmony between the suggestions of the two groups. Thus, it is proposed: to increase the number of technological resources, namely computers, and assigning more time to the TL to be able to work with teachers (at this moment, due mainly to economic constraints, the TL has to respond to other tasks in addition to the library). As Fullan remembers, pedagogical improvement requires additional resources in the form of materials, equipment, space, time and access to new ideas and specialized skills [17]. And in a time of a fastevolving technological environment, schools in general and the SL in particular have to deal with new challenges and need the tools to face it.

\section{REFERENCES}

[1] I. Veiga, C. Barroso, J.A. Calixto, T. Calçada and T. Gaspar, Lançar a Rede de Bibliotecas Escolares. Lisboa: Ministério da Educação, 1997.

[2] E. Conde, I. Mendinhos and P. Correia (coords.), Aprender com a biblioteca escolar: Referencial de aprendizagens associadas ao trabalho das bibliotecas escolares na educação pré-escolar e nos ensinos básico e secundário (2. ${ }^{a}$ ed.). Lisboa: ME/RBE, 2017. Retrieved from http://www.rbe.min-edu.pt/np4/file/1906/referencial_2017.pdf

[3] E. Conde, R. M. Martins and G. Bastos, Modelo de avaliação da biblioteca escolar, Lisboa: ME/RBE, 2011.

[4] G. Bastos and R. Martins, "Portuguese school libraries: The design and implementation of a selfevaluation model" in Preparing pupils and student for the future. Annual Conference of the International Association of School Librarianship, Abano Terme, CD (pp. 1-11), 2009. Retrieved from http://hdl.handle.net/10400.2/2575

[5] G. Bastos, E. Conde and R. M. Martins, "A self-evaluation model for school libraries in Portugal" in Global Perspectives on School Libraries: Projects and Practices (L. Marquardt \& D. Oberg eds.), pp. 11-21, Berlin: De Gruyter Saur, 2011.

[6] P. Matthews, L. Klaver, J. Lannert, G. O. Conluain and A. Ventura, Política educativa para o primeiro ciclo do ensino básico: 2005-2008: Avaliação internacional, Lisboa: Gabinete de Estatística e Planeamento da Educação, 2009.

[7] J. W. Creswell, Projeto de pesquisa: Métodos qualitativo, quantitativo e misto ( $2^{\mathrm{a}}$ ed.). Porto Alegre, Brasil: Artemed, 2007.

[8] J. Bell, Doing your research project ( $3^{\text {rd }}$ ed.), Milton Keynes: Open University Press, 1999.

[9] R. E. Stake, Art of case study research. Thousand Oasks: Sage Publications, 1995.

[10] R. C. Bogdan and S. K. Biklen, Investigação qualitativa em educação: Uma introdução à teoria e aos métodos, Porto: Porto Editora, 1994.

[11] D. das N. Domingues and M. M. M. da Silva (coord.), A educação escolar em mudança: Professores e prática pedagógica nas escolas (Vol. 2). Lisboa: Instituto Superior de Ciências Sociais e Políticas, 1998.

[12] J. A. M. Gonçalves, "A carreira das professoras do ensino primário", in Vidas de professores, (A. Nóvoa, org.), Porto: Porto Editora, pp. 141-169, 2000.

[13] IFLA School Libraries Section Standing Committee, IFLA School Library Guidelines, 2nd revised edition. IFLA. 2015. Retrieved from https://www.ifla.org/files/assets/school-libraries-resourcecenters/publications/ ifla-school-library-guidelines.pdf

[14] S. M. Marques, A promoção da leitura na biblioteca escolar do $1 .^{\circ}$ CEB: 10 anos do programa RBE no concelho de Vila Franca de Xira, Dissertação de mestrado, Universidade de Lisboa, 2009. Retrieved from http://hdl.handle.net/10451/2094 
[15] P. C. Valente, A promoção da leitura em contexto educacional: Estudo de caso sobre a aplicação do Plano Nacional de Leitura e sobre as práticas de leitura numa turma do $4^{\circ}$ ano do $1^{\circ}$ ciclo do ensino básico de um agrupamento vertical de escolas do Norte de Portugal, Dissertação de mestrado, Universidade Portucalense, Porto, 2013. Retrieved from http://hdl.handle.net/ $11328 / 1530$

[16] A. Zmuda and V. H. Harada, "Refraiming the library media specialist as a learning specialist", School Library Media Activities Monthly, vol. 24, no. 8, pp. 42-46, 2008.

[17] M. Fullan, Leading in a culture of change, San Francisco: Jossey-Bass, 2001. 